\title{
PEMBELAJARAN BERBASIS KOMPUTER \\ PADA MATA KULIAH PROGRAM LINIER \\ UNTUK MENGEMBANGKAN BERPIKIR KRITIS
}

\author{
Oleh \\ Ni Ketut Kertiasih \\ Jurusan Manajemen Informatika, FTK, Undiksha
}

\begin{abstract}
Abstrak
Pemahaman konseptual program linier dibutuhkan untuk membantu dalam menganalisis permasalahan sumber daya meliputi tenaga kerja, bahan baku, dana, dan sebagainya. Hasil analisis tersebut digunakan untuk pengambilan keputusan terkait dengan optimalisasi tujuan yang hendak dicapai. Dalam melakukan analisa dibutuhkan kemampuan berpikir untuk merepresentasikan dan menerjemahkan masalah-masalah sumber daya. Pembelajaran dengan metoda ceramah, belum bisa memfasilitasi pemahaman secara optimal. Upaya yang dapat dilakukan adalah dengan menerapkan pembelajaran berbasis komputer guna menambah pemahaman terhadap program linier. Dengan pembelajaran berbasis komputer dapat mengembangkan cara berpikir kritis, sehingga mampu untuk melakukan menganalisa permasalahan sumber daya untuk dapat mengambil keputusan secara optimal.
\end{abstract}

Kata kunci: pembelajaran berbasis komputer, program linier, berpikir kritis

\begin{abstract}
Conceptual understanding of linear programs needed to help analyze the problems in resources include labor, raw materials, funds, and so forth. The analysis results were used to making decisions related to the optimization goals to be achieved. In conducting the analysis necessary thinking skills to represent and translate the problems of resources. Learning with lecture method, has not been able to facilitate understanding optimally. Efforts that can be done is to apply computer-based learning in order to increase understanding of the linear program. With computer-based learning to develop critical thinking, thus able to analyze the problems of resources to be able to take an optimal decision.
\end{abstract}

Key words: computer based learning, linear programming, critical thinking

Pembelajaran Berbasis Komputer pada Mata Kuliah......................(Ni Ketut Kertiasih) 


\section{PENDAHULUAN}

Dalam pembelajaran seorang pengajar dituntut kemampuannya untuk mampu menciptakan suasana pembelajaran yang menyenangkan (komunikasi yang produktif), dimana para peserta didik dapat memperoleh kemudahan dalam belajar. Proses pembelajaran pada dasarnya merupakan hubungan sebab akibat antara pengajar dan peserta didik, meskipun tidak setiap perbuatan belajar merupakan akibat dari proses pembelajaran. Belajar dapat terjadi karena proses interaksi antara individu dengan lingkungannya.

Mata kuliah yang ada Jurusan Manajemen Informatika semester 3 salah satunya adalah mata kuliah program linier. Program linear adalah salah satu model matematika yang digunakan untuk menyelesaikan masalah optimisasi, yaitu memaksimumkan atau meminimumkan fungsi tujuan yang bergantung pada sejumlah variabel input. Penyelesaian permasalahan dengan metode dalam program linier adalah untuk melakukan analisis yang nantinya digunakan dalam pengambilan keputusan. Untuk dapat mengambil keputusan yang tepat maka dituntut supaya dapat berpikir secara kritis. Sehingga keputusan yang akan diambil dapat mewujudkan tujuan yang hendak dicapai, seperti untuk memaksimalkan keuntungan dan meminimumkan pengeluarannya (biaya bahan baku, biaya proses produksi, gaji karyawan, transportasi, dan lain-lain).

Dalam proses pembelajaran kehadiran media berbasis komputer mempunyai arti yang cukup penting. Karena dalam kegiatan tersebut ketidakjelasan bahan yang disampaikan dapat dibantu dengan menghadirkan media sebagai perantara. Kerumitan bahan yang disampaikan kepada mahasiswa dapat disederhanakan dengan bantuan media. Media dapat mewakili apa yang kurang mampu dosen ucapkan melalui katakata atau kalimat tertentu. Bahkan keabstrakan bahan dapat dikonkretkan dengan kehadiran media. Dengan demikian mahasiswa lebih mudah mencerna materi pelajaran.

Dengan pembelajaran berbantuan komputer, diharapkan dapat membantu mahasiswa untuk memahami materi program linier dan mampu untuk mengaplikasikannya dalam membantu menyelesaiakan permasalahan dengan menerapkan program linier sebagai solusinya. Berdasarkan hal tersebut, perlu kiranya 
dikaji bagaimana penggunaan pembelajaran berbasis komputer dapat mengembangkan berpikir kritis mahasiswa sehingga mahasiswa dapat membantu menyelesaikan permasalahan terkait dengan pencarian optimalisasi maksimisasi dan minimisasi tujuan. Sehingga dengan hasil penyelesaian tersebut dapat diambil suatu keputusan agar tujuan optimalisasi penggunaan sumber daya dapat tercapai dengan tepat.

\section{PEMBAHASAN}

\section{Model Pembelajaran Berbasis Komputer}

Proses pembelajaran merupakan proses komunikasi antara guru dan peserta didik, yaitu proses penyampaian pesan dari sumber pesan melalui media tertentu ke penerima pesan (Sadimin dalam Putri Rida). Untuk menghindari kesalahan komunikasi digunakan sarana untuk dapat membantu proses komunikasi yang disebut media. Media adalah perantara atau pengantar pesan dari pengirim ke penerima pesan. Media sebagai segala bentuk dan saluran yang digunakan orang untuk menyalurkan pesan/informasi. Dalam hal ini media yang digunakan untuk menyalurkan pesan/informasi adalah media berbasis komputer.

Komputer merupakan salah satu media yang menggunakan media visual berupa gambar, foto, chart, grafik, diagram dan lainnya, audio berupa orang bicara, musik, suara alam gesekan dedaunan, air yang menetes di batu kali, burung berkicau, lenguh suara lembu, kucing mengeong dan lainnya, termasuk media lain yang diakses dari sumber yang amat jauh melaui internet. Pembelajaran yang menggunakan komputer dan perangkat jaringan lainnya yang dikenal sebagai multimedia.

Pentingnya penggunaan media dalam pembelajaran, menurut pendapat Edgare Dale yang mengemukakan teori yang dikenal dengan teori kerucut pengalaman. Dalam dunia pendidikan, penggunaan media/bahan/sarana belajar seringkali menggunakan prinsip Kerucut Pengalaman, yang membutuhkan media belajar seperti buku teks, bahan belajar yang dibuat oleh tenaga pendidik dan "audio-visual". (Sutjiono, 2005). 


\section{Berpikir Kritis}

Secara definitif, berpikir kritis atau critical thinking merupakan kemampuan atau keahlian dalam menggunakan pikiran secara reflektif dan independen, sehingga mampu untuk menghasilkan pikiran yang jernih dan rasional.

Berpikir kritis sebagai proses disiplin cerdas dari konseptualisasi, penerapan, analisis, sintesis dan evaluasi aktif dan berketerampilan yang dikumpulkan dari, atau dihasilkan oleh, observasi, pengalaman, refleksi, penalaran atau komunikasi sebagai sebuah penuntun menuju kepercayaan dan aksi. Selain itu berpikir kritis juga telah didefinisikan sebagai berpikir yang memiliki maksud, masuk akal.

Berpikir kritis adalah sebuah keahlian atau cara yang berguna dan penting dalam pengembangan profesi, karir, maupun kehidupan. Selain itu, berpikir secara jernih dan sistematis, dapat meningkatkan kemampuan untuk mengekspresikan gagasan secara lebih komprehensif. Artinya, berpikir kritis secara tidak langsung menambah kemampuan ber-bahasa dan keahlian presentasi dari orang tersebut.

Keahlian berpikir kritis juga sangat berkaitan dengan kemampuan seseorang untuk menjadi kreatif. Sebab, kreativitas tidak begitu saja muncul secara tiba-tiba sebagai akibat lahirnya ide atau gagasan baru. Ada proses yang terjadi sebelum kreativitas itu terwujud. Proses itu adalah proses berpikir. Seseorang yang kreatif adalah mereka yang mampu membangkitkan pikiran supaya melahirkan gagasan baru yang berguna dan relevan untuk dikerjakan. Ketika ide atau gagasan baru itu bermunculan, keahlian untuk berpikir kritis memiliki peran yang sangat penting.

\section{Program Linier}

Program linier merupakan suatu model atau teknis matematis yang dapat digunakan dalam pemecahan masalah pengalokasian sumber-sumber yang terbatas secara optimal. Sumber-sumber yang dimaksud dapat berupa biaya bahan baku, biaya proses produksi, gaji karyawan, transportasi dan lain-lain. Program linier memiliki empat ciri khusus yang melekat, yaitu: (Nurmatias)

a. penyelesaian masalah mengarah pada pencapaian tujuan maksimisasi atau minimisasi,

b. kendala yang ada membatasi tingkat pencapaian tujuan, 
c. terdiri dari beberapa alternatif penyelesaian,

d. memiliki hubungan matematis yang bersifat linier.

Permasalahan yang dapat diselesaikan dengan menggunakan program linier, diantaranya:

a. masalah kombinasi produksi,yaitu; menentukan berapa jumlah dan jenis produk yang harus dibuat agar diperoleh keuntungan maksimum atau biaya minimum dangan memperhatikan sumber daya yang dimiliki,

b. masalah perencanaan promosi, yaitu; berapa banyak dana yang akan dikeluarkan untuk kegiatan promosi, agar diperoleh efektivitas penggunaan media promosi,

c. masalah diet, yaitu; berapa banyak setiap sumber makanan digunakan untuk membuat produk makanan baru,

d. masalah distribusi/transportasi, yaitu; jumlah produk yang akan dialokasikan ke setiap lokasi pemasaran.

Formulasi yang digunakan dalam menyelesaikan permasalahan dengan menggunakan program linier, meliputi:

a. menentukan variabel yang ingin diketahui dan gambarkan dalam simbul matematik,

b. menentukan tujuan dengan menggambarkan dalam satu sel fungsi linier dari variabel keputusan yang dapat berbentuk maksimum atau minimum,

c. menentukan kendala dalam bentuk persamaan linier atau pertidaksamaan linier dari variabel keputusan.

d. menentukan optimalisasi (maksimisasi atau minimisasi tujuan) yang dihubungkan dengan fungsi tujuan.

\section{Penggunaan Pembelajaran Berbasis Komputer Dalam Pembelajaran Program Linier Untuk Mengembangkan Berpikir Kritis}

Bermacam peralatan dapat digunakan dosen untuk menyampaikan pesan ajaran kepada mahasiswa melalui penglihatan dan pendengaran untuk menghindari 
verbalisme yang masih mungkin terjadi kalau hanya digunakan alat bantu visual semata.

Dilihat dari kenyataan yang ada, bagaimanapun juga dosen memiliki keterbatasan tertentu, baik yang melekat maupun karena hal-hal yang bersifat insidental. Kenyataan ini akan dapat menghambat atau mengganggu proses belajar mahasiswa. Untuk mencapai tujuan dan hasil belajar mahasiswa yang optimal tidak mungkin bila dosen hanya mengandalkan kemampuan dirinya dalam menyajikan bahan ajar tanpa melibatkan media. Apalagi kalau hanya mengandalkan penggunaan metode ceramah, sadar atau tidak akan membuat para mahasiswa mendengarkan secara pasif, dapat menghambat proses belajar yang kreatif dan kurang dinamis.

Pada dasarnya kemampuan, kesiapan, dan minat belajar mahasiswa sangat beragam antara yang satu dengan yang lainnya. Oleh karena itu perlu dipikirkan bagaimana meskipun proses pembelajaran dilakukan secara klasikal, setiap mahasiswa secara individual dapat terpelihara kegiatan, kemampuan dan produktifitas belajarnya meski kecerdasan, kecepatan, dan gaya belajarnya mereka masing-masing berbeda.

Komputer hingga saat ini merupakan satu-satunya media yang memiliki teknologi yang berkemampuan interaktif. Dewasa ini komputer tidak lagi merupakan konsumsi bagi mereka yang bergerak dalam dunia bisnis dan usaha, tetapi telah dimanfaatkan secara luas oleh dunia pendidikan. Penggunaan media secara tepat dan bervariasi dapat meningkatkan belajar aktif. Karena mahasiswa terlepas dari pembelajaran konvensional yang memaksa mahasiswa untuk mengikuti pembelajaran yang tidak menarik dan membosankan, sehingga sekolah tak lebih merupakan bangunan tembok penjara yang menghukum penghuninya untuk mengikuti menerima seluruh ajaran yang ada didalamnya.

Pemanfaatan media berbasis komputer dalam proses pembelajaran sebagai upaya untuk membantu mengembangkan cara berpikir kritis dari mahasiswa. Karena melalui media dapat dijelaskan sesuatu materi pelajaran yang sifatnya abstrak. Dalam proses pembelajaran dosesn memegang peranan kunci dalam usaha pengembangan kemampuan berpikir kritis. Untuk itu dosen perlu memahami strategi pembelajaran atau pendekatan-pendekatan pembelajaran yang tepat agar mahasiswa mampu berpikir kritis.

JPTK, UNDIKSHA, Vol. 7, No. 1, Januari $2010: 21$ - 28 
Berkaitan dengan untuk mengembangkan kemampuan berpikir kritis mahasiswa dan pentingnya berpikir kritis maka perlu upaya perbaikan dan inovasi dalam proses pembelajaran. Untuk meningkatkan kemampuan berpikir kritis, maka digunakan strategi pembelajaran dengan mengadopsi strategi dalam pembelajaran berbantuan komputer. Dengan memanfaatkan media berbasis komputer dalam proses pembelajaran program linier pemahaman mahasiswa terhadap materi mata kuliah menjadi lebih baik dan dapat menimbulkan cara berpikir secara rasional dan kritis. Pengetahuan yang didapatkan melalui proses berpikir kritis mempunyai tingkat pemahaman yang lebih tinggi. Dengan bekal pengetahuan ini mahasiswa dilatih untuk berpikir rasional dan objektif.

Adapun salah satu contoh tampilan materi program linier dengan menggunakan media berbasis seperti terlihat pada gambar 1 .

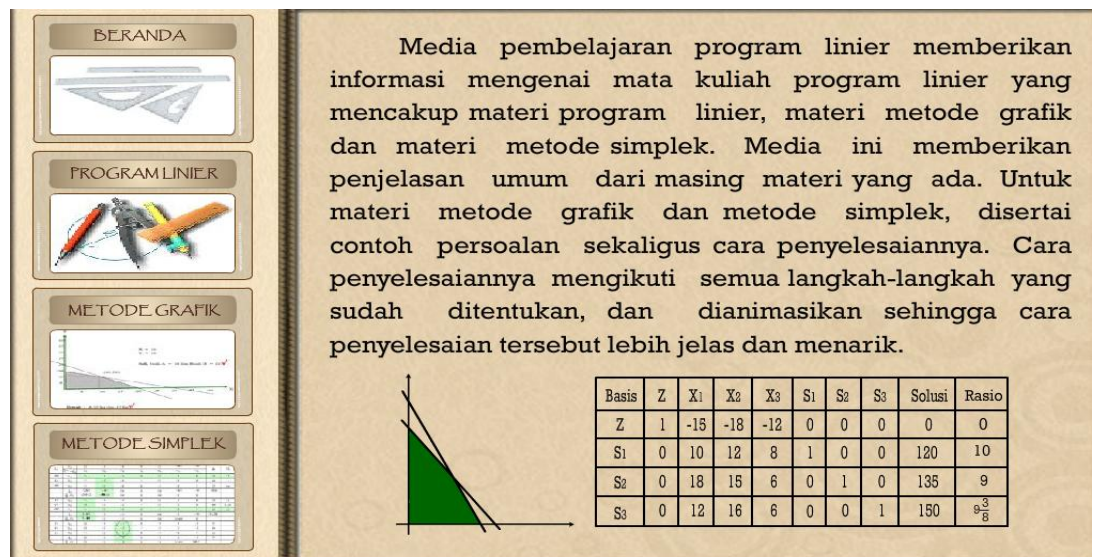

Gambar 1. Tampilan Utama untuk Pemilihan Materi

Pada Gambar 1 merupakan tampilan yang berisi pilihan materi program linier, metode grafik dan metode simplex.

\section{PENUTUP}

Pembelajaran pada hakekatnya merupakan komunikasi yang bersifat timbal balik antara dosen dengan mahasiswa dan mahasiswa dengan lingkungannya. Dalam hal ini, media digunakan sebagai pengantar atau perantara pesan pembelajaran yang akan disampaikan kepada peserta didik. 
Penggunaan media berbasis komputer dalam pembelajaran khususnya mata kuliah program linier dapat meningkatkan keaktifan belajar mahasiswa dan menghilangkan rasa bosan sehingga pembelajaran menjadi menarik, efektif, dan menyenangkan yang pada akhirnya mahasiswa dapat mengembangkan potensi-potensi dan kemampuannya secara optimal. Sehingga dengan menggunakan model pembelajaran berbasis komputer pada proses pembelajaran program linier dapat menimbulkan cara berpikir kritis. Pada akhirnya mahasiswa dapat mencari solusi penyelesaian permasalahan dengan program linier selanjutnya dapat digunakan untuk mengambil keputusan dalam mencapai tujuan optimalisasi maksimisasi misalnya mencari keuntungan dan minimisasi seperti penggunaan biaya.

\section{Daftar Pustaka}

Erianawati "Penggunaan Media Visual (Gambar) Dalam Pembelajaran Anak Hiperaktif Di Lembaga Terapi Anak Altisma Kudus". Tersedia pada http://digilib.unnes.ac.id/gsdl/collect/skripsi/archives/HASH04fd/6a3e1b5f. dir/doc.pdf. diakses tanggal 10 Februari 2010

Nurmatias. Program Linier dengan Penyelesaian Metode Grafik. Modul 2. Jakarta: Pusat Pengembangan Bahan Ajar-UMB.

Putri Rida. "Perancangan Media Pembelajaran Berbasis Komputer Dengan Pemanfaatan Software Incomedia Di Sekolah Menengah Pertama” Tersedia pada http://etd.eprints.ums.ac.id/724/1/A410040136.pdf

Sutjiono, Thomas Wibowo Agung. 2005. "Pendayagunaan Media Pembelajaran" Jurnal Pendidikan Penabur-No.04. Tersedia pada http://www.bpkpenabur.or.id/files/Hal.7684\%20Pendayagunan\%20Media\%20Pembelajaran.pdf

Yanu Endar Prasetyo. "Seni Berpikir Kritis". Tersesida pada http://duniayanu.blogspot.com/2009/03/seni-berpikir-kritis.html. 